\title{
SOCIAL-ECONOMIC FACTORS EFFECTING THE DIVERSITY OF DIETARY CONSUMPTION IN THE SELF SUFFICIENT DIETARY VILLAGE OF KUBU RAYA DISTRICT
}

\author{
Surachman ${ }^{1)}$, Novira Kusrini ${ }^{2)}$, Adi Suyatno ${ }^{2)}$ \\ 1) Student of Magister Manajemen Agrisbisnis \\ 2) Lectures of The Faculty of Agriculture Tanjungpura University
}

\begin{abstract}
The research was conducted in Jeruju Besar village in the district of Kubu Raya and Sungai Bulan village in Sungai Raya District. These two locations were chosen because of its location within program The DEMAPAN (Self Sufficient Dietary Village). The purpose of this research was : (1) to analyze the quality of food consumption in the Desirable Dietary Pattern/DDP communities, Kubu Raya District (DDP score). (2) to analyze the relationship between socio-economic aspects and the diversity of food consumption in the DEMAPAN village in Kubu Raya district.

The research was carried out for 6 months, in which the data collection finished for 5 weeks, i.e. from January to June 2013. Population of this research is the head of the family who live in the Village of Sungai Bulan Sungai Raya District, the locations of DEMAPAN program in 2010, and also in the village of Jeruju Besar, Sungai Kakap District by 2011 . The sample selection was based on Randomize Simplified Sampling method, in which the sample were randomly selected. The research variables were socio-economic factors (income, education, and family size), Score DDP (Desirable Dietary Pattern).

The results showed that the DDP score of 68.52 in the research area is still low compared to West Kalimantan DDP score of 71.79 and score of 100 DDP ideally. DDP score Jeruju Besar Village were not significantly different than the score DDP in Sungai Bulan Village. Factors effecting the DDP Score in Jeruju Besar were income, education, and number of dependants. While at Sungai Bula Village they were family income and number of dependants. So, the factor of income level, education, and number of dependants were key determination of the level of food diversity in the commuity.
\end{abstract}

Keywords : Social-economic, Food Consumption Diversity, Self Sufficient Dietary Village

\section{PENDAHULUAN}

\section{A. Latar Belakang}

Keanekaragaman konsumsi pangan sering diartikan sebagai pengurangan konsumsi beras yang dikompensasi oleh penambahan konsumsi bahan pangan non beras. Salah satu alasan pentingnya diversifikasi pangan bahwa dalam lingkup nasional pengurangan konsumsi beras akan memberikan dampak positif terhadap ketergantungan impor beras dari negara lain.

Beberapa kebijakan pemerintah belum memberikan hasil optimal dalam rangka penganekaragaman konsumsi pangan. Sampai saat ini Indonesia masih menghadapi masalah kualitas konsumsi pangan yang ditunjukkan oleh skor pola pangan harapan $(\mathrm{PPH})$ dan rapuhnya ketahanan pangan. Berdasarkan data susenas skor PPH baru mencapai 78,2 yang mana skor idealnya adalah 100, dimana skor PPH Provnsi Kalimantan Barat pada tahun 2010 mencapai 71,9. Sedangkan indikator lemahnya ketahanan pangan di tingkat rumah tangga diindikasikan oleh (a). Jumlah penduduk rawan pangan (konsumsinya $<90 \%$ dari AKG) yang masih cukup besar yaitu 52,33 juta jiwa pada tahun 2002. Dari jumlah tersebut 15,48 juta jiwa diantaranya merupakan penduduk sangat rawan (konsumsinya $<70 \%$ AKG); (b). Balita kurang gizi 
masih cukup besar yaitu 5,02 juta pada tahun 2002 dan 5,12 juta pada tahun 2003 (Dewan Ketahanan Pangan, 2006).

Forum kerja penganekaragaman (2003) dan Monek (2007) mengatakan hambatan dalam penganekaragaman pangan diantaranya dikarenakan (a) Tingkat pengetahuan masyarakat Indonesia terutama kelas menengah ke bawah relatif rendah, (b) Budaya makan adalah kebiasaan yang sulit untuk diubah, (c) Beras diposisikan sebagai makanan unggulan dan (d) Inovasi dalam bidang aneka pangan relatif terlambat.

Selain faktor produksi, ketersediaan, dan budaya, pola konsumsi pangan juga dipengaruhi oleh faktor ekonomi, sosial, pendidikan, gaya hidup, pengetahuan, aksessibilitas dan sebagainya. Faktor prestise dari pangan kadang kala menjadi sangat menonjol sebagai faktor penentu daya terima pangan (Martianto dan Ariani,2004). Bedasarkan penelitian Munparidi (2010) menunjukkan bahwa konsumsi pangan berhubungan dengan ukuran keluarga dan pendapatan, dimana prioritas 1 dan 2 pengeluaran masyarakat untuk memenuhi makanan pokok dan pangan hewani.

Memperhatikan uraian di atas maka salah satu upaya yang dapat dilakukan adalah dengan melakukan kajian tentang perilaku konsumsi pangan yang dicerminkan oleh perubahan kuantitas dan keanekaragaman konsumsi pangan di masyarakat akibat faktor sosial ekonomi yang berbeda. Keberhasilan dalam kajian tersebut diharapkan dapat memberikan masukan dan mempercepat pengembangan penganekaragaman di berbagai daerah dengan tetap memperhatikan kekhasan di masing-masing daerah.

Berdasarkan Tabel 1. mengenai sumber karbohidrat di Kabupaten Kubu Raya, maka dapat dilihat bahwa kecamatan yang mempunyai sumber karbohidrat yaitu padi sawah, jagung, ketela pohon dan ubi jalar yang baik adalah Kecamatan Sungai Raya. Berbanding lurus dengan data penduduk yang ternyata kebanyakan penduduk miskin juga daerah Kecamatan Sungai Raya dan Kecamatan Sungai Kakap (Tabel 2), padahal sumber karbohidratnya tinggi.

Melihat fenomena yang terjadi berdasarkan data yang ada, maka perlunya melakukan penelitian mengenai "Kajian faktor sosial ekonomi keluarga terhadap perilaku konsumsi diversifikasi pangan di Kecamatan Sungai Raya dan Kecamatan Sungai Kakap Kabupaten Kubu Raya".

Tabel 1. Sumber Karbohidrat Kabupaten Kubu Raya

\begin{tabular}{cccccc}
\hline \multirow{2}{*}{ No. } & \multirow{2}{*}{ Kecamatan } & \multicolumn{4}{c}{ Luas Tanam (Ha) } \\
\cline { 3 - 6 } & & Padi Sawah & Jagung & Ubi Kayu & Ubi Jalar \\
\hline $\mathbf{1}$ & $\mathbf{2}$ & $\mathbf{3}$ & $\mathbf{4}$ & $\mathbf{5}$ & $\mathbf{6}$ \\
\hline 1 & Batu Ampar & 6.911 & 86 & 103 & 55 \\
2 & Terentang & 3.138 & 160 & 118 & 62 \\
3 & Kubu & 9.938 & 338 & 67 & 45 \\
4 & Teluk Pakedai & 3.728 & 121 & 102 & 12 \\
5 & Sungai Kakap & 15.373 & 1.209 & 29 & 35 \\
6 & Rasau Jaya & 3.082 & 566 & 56 & 18 \\
7 & Sungai Raya & 8.163 & 4.136 & 494 & 191 \\
8 & Sungai Ambawang & 2.048 & 589 & 82 & 16 \\
9 & Kuala Mandor B & 1.940 & 175 & 78 & - \\
\hline \multicolumn{2}{r}{ Jumlah } & $\mathbf{5 4 . 3 6 6}$ & $\mathbf{7 . 3 8 0}$ & $\mathbf{1 . 1 2 9}$ & $\mathbf{4 3 4}$ \\
\hline
\end{tabular}

Sumber : Dinas Pertanian dan Peternakan Kabupaten Kubu Raya, 2009 
Tabel 2. Data Keluarga Miskin Kabupaten Kubu RayaTahun 2008

\begin{tabular}{|c|c|c|c|c|c|}
\hline No. & Kecamatan & $\begin{array}{l}\text { Jumlah } \\
\text { Penduduk }\end{array}$ & Jumlah KK & $\begin{array}{c}\text { Jumlah KK } \\
\text { Miskin }\end{array}$ & $\begin{array}{c}\text { Jumlah } \\
\text { Jiwa Miskin }\end{array}$ \\
\hline $\mathbf{1}$ & 2 & 3 & 4 & 5 & 6 \\
\hline 1 & Batu Ampar & 32.410 & 8.667 & 5.060 & 22.041 \\
\hline 2 & Terentang & 8.637 & 2.627 & 1.572 & 6.204 \\
\hline 3 & Kubu & 33.299 & 9.451 & 3.955 & 16.932 \\
\hline 4 & Teluk Pakedai & 16.361 & 4.940 & 2.746 & 11.835 \\
\hline 5 & Sungai Kakap & 95.611 & 20.487 & 9.972 & 42.937 \\
\hline 6 & Rasau Jaya & 21.599 & 6.109 & 1.432 & 5.718 \\
\hline 7 & SungaiRaya & 206.981 & 43.212 & 14.422 & 66.665 \\
\hline 8 & Sungai Ambawang & 59.645 & 14.606 & 7.269 & 34.416 \\
\hline \multirow[t]{2}{*}{9.} & Kuala Mandor B & 21.415 & 5.161 & 2.948 & 14.152 \\
\hline & Jumlah & 495.958 & 94.793 & 49.376 & 220.900 \\
\hline Sumb & $\begin{array}{l}\text { Badan Pem } \\
\text { dan KB Kab }\end{array}$ & Masyarakat, & berdayaar & mpuan, $F$ & 它 \\
\hline
\end{tabular}

\section{B. Perumusan Masalah}

Berdasarkan latar belakang diatas maka masalah penelitian yang akan diteliti adalah sebagai berikut:

1. Bagaimana kualitas konsumsi pangan masyarakat di Desa Mandiri Pangan, Kabupaten Kubu Raya (skor PPH)?

2. Bagaimana keterkaitan antara aspek sosial ekonomi terhadap keanekaragaman konsumsi pangan Desa Mandiri Pangan, Kabupaten Kubu Raya?

\section{Tujuan Penelitian}

Adapun tujuan penelitiannya adalah sebagai berikut :

1. Menganalisis kualitas konsumsi pangan masyarakat di Desa Mandiri Pangan, Kabupaten Kubu Raya (skor PPH).

2. Menganalisis hubungan antara aspek sosial ekonomi keluarga terhadap keanekaragaman konsumsi pangan Desa Mandiri Pangan, Kabupaten Kubu Raya.

\section{KERANGKA PEMIKIRAN}

\section{A. Tinjauan Pustaka}

\section{a. Diversifikasi Pangan}

Dilihat dari sisi produksi atau penawaran, diversifikasi pangan berarti menghasilkan komoditas pangan yang lebih beragam dengan sumberdaya tertentu yang digunakan secara optimal. Sedangkan dari sisi permintaan atau konsumen, diversifikasi pangan berarti penganekaragaman pemenuhan kebutuhan terhadap komoditas pertaian (Bunasor, 1989). Menurut pandangan ahli gizi, diversifikasi konsumsi pangan merupakan salah satu dari diversifikasi pangan yang pada prinsipnya merupakan landasan bagi terciptanya ketahanan pangan. Pangan yang beragam akan dapat memenuhi kebutuhan gizi manusia, di samping itu diversifikasi konsumsi pangan juga memiliki dimensi lain bagi ketahanan pangan. 
Adapun tujuan khusus percepatan diversifikasi konsumsi pangan adalah untuk mendorong tercapainya:

a. Peningkatan permintaan masyarakat terhadap aneka pangan baik pangan segar, olahan maupun siap saji. Tujuan ini dicapai melalui peningkatan pengetahuan dan kesadaran gizi seimbang sejak usia dini, pengembangan kegiatan pemberdayaan ekonomi rumah tangga, serta promosi dan gerakan/pemasaran sosial tentang diversifikasi konsumsi pangan berbasis sumberdaya dan kelembagaan lokal kepada aparat dan seluruh komponen masyarakat.

b. Peningkatan ketersediaan aneka ragam pangan segar dan olahan berbasis sumberdaya lokal. Tujuan ini dicapai melalui pengembangan bisnis dan industri pengolahan aneka pangan, baik sumber karbohidrat non beras maupun aneka pangan sumber protein, vitamin dan mineral nabati dan hewani berbasis sumberdaya lokal yang aman, terjangkau, dapat diterima secara sosial, ekonomi dan budaya. serta mampu menggerakkan sosial ekonomi petani dan UMKM.

c. Penguatan dan peningkatan partisipasi pemerintah daerah dan seluruh potensi daerah dalam fasilitasi dan pengembangan progam dan kegiatan diversifikasi konsumsi pangan berbasis sumber daya dan kelembagaan lokal.

Pedoman umum gerakan percepatan diversifikasi konsumsi pangan 20072015, menyebutkan bahwa sasaran percepatan diversifikasi konsumsi pangan yang hendak dicapai adalah pola konsumsi pangan beragam, bergizi seimbang dan aman yang dicerminkan dengan tercapainya skor PPH sekurang-kurangnya 85 pada tahun 2011 dan mendekati ideal 100 pada tahun 2015.

Program diversifikasi pangan dan gizi dilaksanakan di pedesaan dengan katagori wilayah miskin dan rawan gizi melalui pembinaan wanita kelompok tani. Program diversifikasi pangan mengarah pada pembinaan kesadaran keluarga tani melalui pemanfaatan lahan pekerangan. Program diversifikasi pangan diupayakan untuk peningkatan ketersediaan penganekaragaman pangan ditingkat keluarga. Program ini bertujuan sesuai dengan upaya pemerintah untuk menurunkan laju konsumsi beras perkapita pada tingkat Nasional.

Program diversifikasi pangan juga dilaksanakan dengan gerakan Aku Cinta Makanan Indonesia (ACMI). Program ACMI bertujuan untuk peningkatan; popularitas makanan tradisional yang standar mutu dan keamanan pangan terjamin bagi konsumen, budaya makan tradisional dan citra serta pelestarian makanan Indonesia melalui pedagang kaki lima juga jasa boga.

\section{b. Kuantitas Dan Kualitas Konsumsi Pangan}

Hasil pertemuan para ahli pangan dan gizi yang diselenggarakan oleh FAO Regional Office For Asia and Pasifik (RAPA) di Bangkok tahun 1988, dikemukakan bahwa pengertian Pola Pangan Harapan (PPH) adalah komposisi dan jumlah kelompok pangan utama harus memenuhi kebutuhan energi dan gizi. Pola Pangan Harapan adalah susunan beragam makanan yang kontribusi energinya baik mutlak maupun relatif memenuhi kebutuhan gizi secara kuantitas, kualitas serta keragaman dengan memperhatikan aspek social ekonomi,cita rasa budaya dan agama. Dengan menggunakan sistem skor yang dilakukan oleh FAO RAPA, maka komposisi Pola Pangan Harapan (PPH) diharapkan mempunyai skor mutu sebesar 100. Susunan Pola Pangan Harapan (PPH), telah disepakati dalam Widyakarya Nasional Pangan dan Gizi (WNPG) tahun 1998 dan disempurnakan pada WNPG VIII tahun 2004. 


\section{c. Pola Pangan Harapan}

Hasil pertemuan para ahli pangan dan gizi yang diselenggarakan oleh FAO Regional Office For Asia and Pasifik (RAPA) di Bangkok tahun 1988, dikemukakan bahwa susunan bahan makanan yang baik adalah apabila mengandung 10-12\% energi dari protein, $20-25 \%$ dari lemak dan sisanya dari karbohidrat. Namun menurut Suhardjo (1994), untuk orang Indonesia sumbangan lemak tidak perlu sebesar itu, tapi cukup $18-22 \%$ sehingga sisanya $66-77 \%$ disediakan oleh karbohidrat. Lemak tersebut sebaiknya terdiri dari 1 bagian lemak jenuh dan 2 bagian lemak tidak jenuh. Dengan menggunakan sistem skor yang dilakukan oleh FAO RAPA, maka komposisi Pola Pangan Harapan (PPH) diharapkan mempunyai skor mutu sebesar 100. Susunan Pola Pangan Harapan (PPH) telah disepakati dalam Widyakarya Nasional Pangan dan Gizi (WNPG) tahun 1998 dan disempurnakan pada WNPG VIII tahun 2004. Dalam Widyakarya Nasional kecukupan konsumsi energi mutlak orang Indonesia sebesar $2.000 \mathrm{k}$ kal per orang per hari, dan untuk tingkat ketersediaan sebagai Angka Kecukupan Energi (AKE) sebesar $2.200 \mathrm{k}$ kal orang per hari atau $10 \%$ di atas tingkat konsumsi.

Pola Pangan Harapan (PPH) merupakan salah satu alat analisis terhadap pangan pada tiap kelompok bahan makanan. Hasil perhitungan PPH Kalimantan Barat dibandingkan dengan standar nasional akan diketahui bahan makanan mana yang perlu ditingkatkan, dikurangi atau dipertahankan. Berdasarkan hasil Widyakarya Nasional Pangan dan Gizi (WNPG) Tahun 1998 yang disempurnakan pada WNPG VIII tahun 2004 sebagian besar konsumsi pangan nasional adalah padi-padian, dimana memberi kontribusi terhadap total konsumsi sebesar 50 persen, dan terendah adalah konsumsi buah/biji berminyak yang sebesar memberi kontribusi 3 persen terhadap total konsumsi.

\section{d. Pola Pangan Harapan Kalimantan Barat dan Nasional}

Penurunan konsumsi energi penduduk Kalimantan Barat tahun 2008 - 2010, setelah dibandingkan dengan Skor Maksimum (Skor Standar Nasional) juga diikuti dengan penurunan yang hampir sama pada Skor AKG dan Skor PPH untuk tingkat konsumsi. Penurunan Skor AKG dan Skor PPH dari tahun 2008 - 2010 ini mengindikasikan bahwa di samping mengalami penurunan secara kuantitas, konsumsi energi penduduk Kalimantan Barat dari tahun 2008 - 2010 juga mengalami penurunan secara kualitas.

Berdasarkan Hasil Analisis PPH pada Tahun 2011 Skor AKG dan Skor PPH Tahun 2010 kualitas konsumsi energi Kalimantan Barat mencapai 77,23 untuk AKG dan 71,79 untuk PPH. Gambaran perkembangan Skor AKG dan Skor PPH Konsumsi Energi di Provinsi Kalimantan Barat Tahun 2008 - 2010 sebagaimana pada Grafik 1.

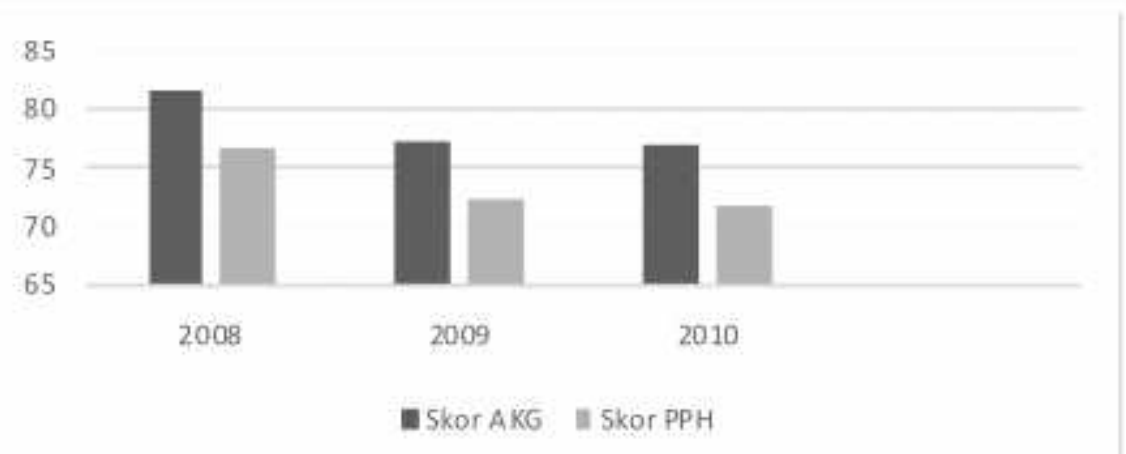

Grafik 1. Perkembangan Skor AKG dan Skor PPH Konsumsi Energi Di Provinsi Kalimantan Barat Tahun 2008 - 2010 
Perkembangan Konsumsi Energi, \% AKG, Skor Aktual, Skor AKG dan Skor PPH Tahun 2008 - 2010 di Provinsi Kalimantan Barat dapat dilihat pada Tabel berikut.

Tabel 3. Perkembangan Konsumsi Energi, \% AKG, Skor Aktual, Skor AKG dan Skor PPH Tahun 2008 - 2010 Di Provinsi Kalimantan Barat

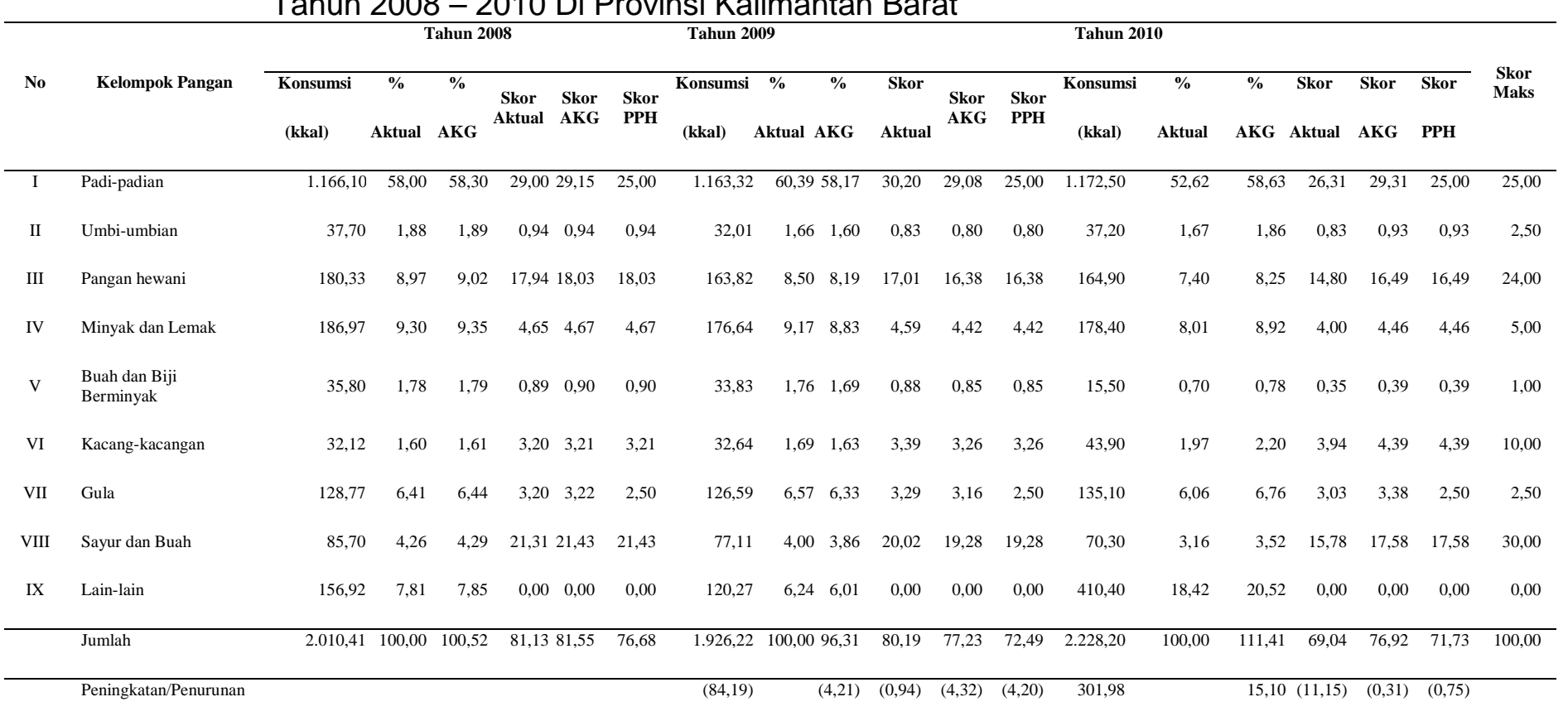

Ket : Angka Konsumsi Energi Berdasarkan Susenas BPS Tahun 1999, 2002, 2005, 2008, 2009 serta 2010 yang rincian per Kelompok Pangannya Hasil Olahan Badan Ketahanan Pangan

Berdasarkan skor AKG hasil analisis PPH Tahun 2010 per Kelompok Pangan pada tingkat konsumsi yang dibandingkan dengan Skor ideal (Skor Maksimal) per Kelompok Pangan, maka diperoleh dua kategori utama yaitu :

1) Kategori pertama, kelompok pangan yang Skor AKG Kalimantan Barat lebih besar dari Skor Standar Nasional yaitu Padi-padian dan gula.

2) Kategori kedua, kelompok pangan yang Skor AKG Kalimantan Barat jauh di bawah Skor Standar Nasional, yaitu umbi-umbian, pangan hewani, minyak dan lemak, buah dan biji berminyak, kacang-kacangan serta sayur dan buah.

\section{B. Penelitian Terdahulu}

Menurut Purwaningsih Yunastiti, Slamet Hartono, Masyhuri, Jangkung Handoyo Mulyo (2009) dalam penelitiannya mengenai Pola Pengeluaran Pangan Rumah Tangga Menurut Tingkat Ketahanan Pangan di Propinsi Jawa Tengah. Hasil penelitian menunjukkan terdapat perbedaan yang cukup besar dalam proporsi pengeluaran pangan antara rumah tangga tahan dan kurang pangan dengan rumah tangga rentan dan rawan pangan. Pada setiap kelompok rumah tangga menurut tingkat ketahanan pangan, rumah tangga di wilayah perkotaan mempunyai proporsi pengeluaran beras lebih kecil dibanding dengan rumah tangga di wilayah pedesaan. Selanjutnya hasil penelitian yang dilakukan oleh Ni Made Suyastiri Y.P (2008) mengenai Diversifikasi Konsumsi Pangan Pokok Berbasis Potensi Lokal Dalam Mewujudkan Ketahanan Pangan Rumahtangga Pedesaan di Kecamatan Semin Kabupaten Gunung Kidul, menyampaikan bahwa upaya mewujudkan ketahanan pangan dan mengurangi ketergantungan masyarakat pada beras rumahtangga 
pedesaan di Kecamatan Semin memanfaatkan sumberdaya lokal yaitu dengan menggali potensi lokal yang berbasis non beras untuk memenuhi kebutuhan pangannya. Faktor-faktor yang mempengaruhi pola diversifikasi konsumsi pangan dalam mewujudkan ketahanan pangan pada rumahtangga pedesaan adalah pendapatan rumahtangga, harga pangan dan jumlah anggota keluarga.

Dalam prosiding, hasil penelitian yang dilakukan oleh Mardiana Ratna Sari dan Bambang Prishardoyo (2009) mengenai Faktor - Faktor Yang Mempengaruhi Kerawanan Pangan Rumah Tangga Miskin Di Desa Wiru Kecamatan Bringin Kabupaten Semarang, menyampaikan bahwa pendapatan, pendidikan dan kepemilikan aset produktif berpengaruh terhadap kerawanan pangan di Desa Wiru Kecamatan Bringin Kabupaten Semarang. Kontribusinya sebesar 52\% dan sisanya $48 \%$ tidak diteliti dalam penelitian ini.

Lebih lanjut penelitian Munparidi (2010) mengenai Pengaruh Pendapatan dan Ukuran Keluarga Terhadap Pola Konsumsi Studi Kasus : Desa Ulak Kerbau Lama Kecamatan Tanjung Raja Kabupaten Ogan Ilir. Hasil penelitian menunjukkan bahwa proporsi alokasi pengeluaran untuk konsumsi pangan berbanding terbalik dengan besarnya pendapatan total keluarga. Sebaliknya proporsi alokasi pengeluaran untuk konsumsi non pangan berbanding lurus dengan pendapatan total keluarga, besarnya ukuran keluarga tidak berpengaruh secara signifikan terhadap pola konsumsi rumah tangga.

\section{Kerangka Konsep}

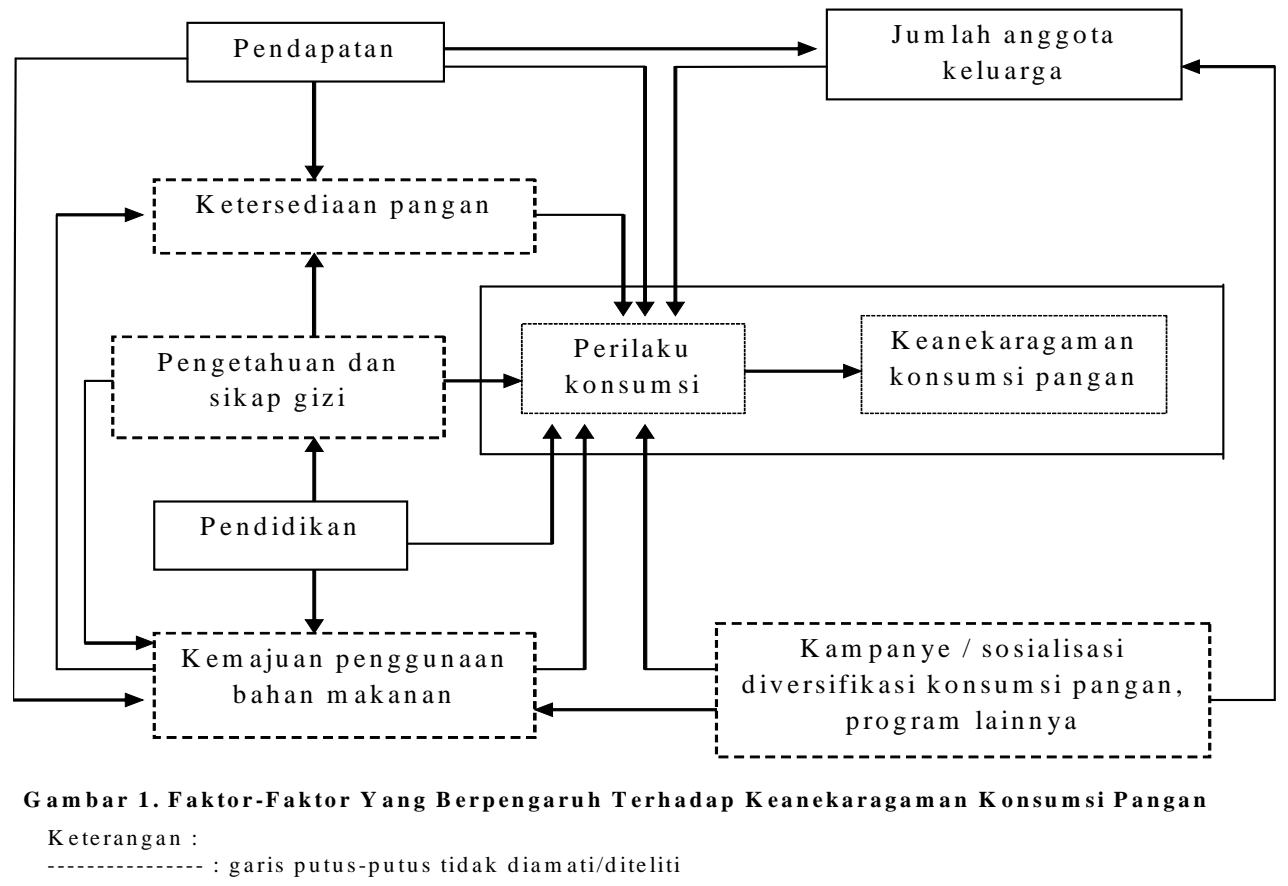

Pada prinsipnya kuantitas dan keanekaragam konsumsi pangan akan ditentukan oleh perilaku konsumsi pangan. Perilaku konsumsi pangan yang terjadi di masyarakat akan dipengaruhi oleh berbagai faktor. Faktor yang diduga berpengaruh kuat adalah aspek sosial ekonomi seperti pendapatan, pendidikan dan jumlah tanggungan keluarga (Gambar 1). 
Faktor lain yang juga dominan mempengaruhi keanekaragaman konsumsi pangan adalah pengetahuan dan sikap gizi. Pengetahuan dan sikap gizi ini berasal dari tingkat pendidikan masyarakat. Jika tingkat pendidikan baik maka pengetahuan dan sikap gizi juga semakin baik.

Keanekaragaman konsumsi pangan dapat dinilai dengan metode PPH. Untuk melihat nilai PPH digunakan skor PPH. Jika nilai skor PPH semakin tinggi (semakin mendekati 100), mengindikasikan konsumsi pangan semakin beragam dan bergizi seimbang.

\section{Hipotesis}

1) Diduga skor PPH di Desa Mandiri Pangan di bawah skor ideal.

2) Diduga faktor sosial dan ekonomi keluarga mempengaruhi tingkat keanekaragaman konsumsi pangan di Desa Mandiri Pangan.

\section{METODE PENELITIAN}

Metode yang digunakan adalah metode survey. Penelitian ini dilakukan di wilayah Kabupaten Kubu Raya, yaitu di Kecamatan Sungai Kakap Desa Jeruju Besar dan Kecamatan Sungai Raya Desa Sungai Bulan. Pemilihan lokasi di dasarkan pada pertimbangan bahwa desa tersebut termasuk dalam program DEMAPAN (Desa Mandiri Pangan). Penelitian ini dilakukan selama 6 bulan dengan lama pengambilan data selama 5 minggu, yakni dari Bulan Januari sampai dengan Bulan Juni 2013.

Populasi pada penelitian ini adalah kepala keluarga yang berdomisili di lokasi DEMAPAN yaitu sebanyak $573 \mathrm{KK}$ di desa sungai bulan dan $2.013 \mathrm{KK}$ di desa jeruju besar. Pemilihan sampel didasarkan metode Simple Random Sampling (Acak Sederhana), dimana sampel dipilih secara acak. Penentuan jumlah sampel rumah tangga digunakan rumus Slovin (Sugiyono, 2011). Adapun rumus Slovin, yaitu:

$$
\mathrm{n}=\frac{\mathrm{N}}{1+N \cdot \mathrm{e}^{2}}
$$

Dimana:

$\mathrm{n}=$ Jumlah sampel

$\mathrm{N}=$ Jumlah populasi

$\mathrm{e}^{2}=$ Persen kelonggaran ketidaktelitian karena kesalahan pengambilan sampel yang masih bisa ditolelir

Jumlah sampel penelitian berdasarkan perhitungan slovin adalah sebanyak 62 KK di desa sungai bulan dan $67 \mathrm{KK}$ di desa jeruju besar.

Jenis data yang dikumpulkan terdiri dari data primer dan data sekunder. Data primer meliputi status ekonomi keluarga, besar keluarga, pendidikan isteri dan suami, pendidikan non formal/pelatihan/kursus yang pernah diikuti, pembinaan di bidang pangan gizi dan kesehatan (bila dapat), umur isteri dan suami, konsumsi pangan, pengetahuan gizi dan pangan, sikap gizi dan pangan. Data skunder yang dikumpulkan meliputi: Keadaan umum wilayah penelitian (fasilitas sarana perekonomian, kesehatan, pendidikan, jenis pekerjaan penduduk), program yang berkaitan dengan diversifikasi konsumsi pangan untuk wilayah yang bersangkutan. 
Adapun variabel yang diteliti dalam penelitian ini antara lain skor pola pangan harapan $(\mathrm{PPH})$, pendapatan keluarga pendidikan ibu/ayah dan jumlah anggota keluarga. Teknik analisis adalah

Analisis data adalah dengan metode menghitung skor PPH masyarakat, dan perhitungan regresi. Metode menghitung skor PPH Skor PPH bertujuan untuk menganalisis kualitas konsumsi pangan masyarakat. Metode perhitungan regresi untuk melihat pengaruh aspek sosial ekonomi terhadap keanekaragaman konsumsi pangan.

\section{HASIL DAN PEMBAHASAN}

\section{A. Gambaran Umum Daerah Penelitian}

\section{Keadaan Geografis}

Luas wilayah Desa Jeruju Besar adalah 711,84 Ha. Secara administratif batas-batas wilayah Desa Jeruju Besar adalah sebagai berikut

- Sebelah Utara berbatasan dengan Desa Sungai Kupah

- Sebelah Selatan berbatasan dengan Desa Sungai Itik

- Sebelah Barat berbatasan dengan Laut Natuna

- Sebelah Timur berbatasan dengan Desa Sungai Rengas

Luas wilayah Desa Sungai Bulan adalah $883 \mathrm{Ha}$ yang terdiri dari 5 dusun yaitu Dusun Wonodadi, Dusun Wonosari, Dusun Wonomulyo, Dusun Wonorejo dan Dusun Teluk Binjai. Secara administratif batas-batas wilayah Desa Sungai Bulan adalah sebagai berikut :

- Sebelah Utara berbatasan dengan Sungai Asam

- Sebelah Selatan berbatasan dengan Sungai Punggur Besar

- Sebelah Barat berbatasan dengan Rasau Jaya

- Sebelah Timur berbatasan dengan Terentang

\section{Keadaan Topografi}

Kondisi topografi Desa Jeruju Besar meliputi dataran rendah yang berbatasan dengan pantai pada bagian sisi barat. Wilayah Desa Jeruju Besar relative datar dengan ketinggian tempat antara 1-1,5 $\mathrm{m}$ di atas permukaan laut. Karena itu kondisi drainase cukup baik dengan kesuburan tanah yang sedang. Desa Jeruju Besar dialiri oleh Sungai Kupah dan Sungai Rengas. Sedangkan Desa Sungai Bulan merupakan daerah datar. Kondisi topografi Desa Sungai Bulan merupakan daerah dataran rendah dengan ketinggian 1 meter DPL.

\section{Keadaan Iklim}

Iklim merupakan suatu faktor penting yang mempengaruhi keberhasilan usaha pertanian. Keadaan iklim sangat mempengaruhi pertumbuhan dan perkembangan tanaman yang dibudidayakan petani, yaitu pengaruh curah hujan, suhu kelembaban, lama penyinaran dan tinggi rendahnya muka air tanah. Disamping pengaruh pasang surut air, iklim juga merupakan faktor yang cukup penting dalam menentukan musim tanam. Desa Jeruju Besar dipengaruhi oleh dua musim, yaitu musim penghujan dan musim kemarau. Dengan curah hujan antara $250-380 \mathrm{~mm}$ per bulan. Suhu rata-rata harian 27-32 ${ }^{\circ} \mathrm{C}$ (Monografi Desa Jeruju Besar, 2011). Sedangkan Desa Sungai Bulan memiliki curah hujan antara 207 - $395 \mathrm{~mm}$ perbulan, dengan suhu $27-31^{\circ} \mathrm{C}$. 


\section{Keadaan Demografi}

\section{1). Jumlah penduduk}

Penduduk memegang peranan penting di dalam suatu daerah. Keberhasilan pembangunan sangat tergantung dari aktivitas dan jumlah penduduk. Berdasarkan data Monografi Desa Jeruju Besar terdiri dari 6.038 jiwa (2.013 KK) dan Desa Sungai Bulan terdiri dari 2.471 jiwa $(573 \mathrm{KK})$. Jumlah penduduk berdasarkan jenis kelamin dapat dilihat pada tabel 4 . berikut.

Tabel 4. Jumlah Penduduk Desa Jeruju Besar dan Desa Sungai Bulan Menurut Jenis Kelamin

\begin{tabular}{lcc}
\hline \multirow{2}{*}{ Jenis Kelamin } & \multicolumn{2}{c}{ Jumlah Penduduk (Jiwa) } \\
\cline { 2 - 3 } & Jeruju Besar & Sungai Bulan \\
\hline Laki-Laki & 3.035 & 1.246 \\
Perempuan & 3.003 & 1.325 \\
Total & 6.038 & 2.471 \\
\hline
\end{tabular}

Sumber : Monografi Desa Jeruju Besar dan Desa Sungai Bulan, 2011

\section{2). Pendidikan}

Pendidikan merupakan salah satu bentuk investasi bagi masyarakat, dengan salah satu tujuannya untuk meningkatkan kecerdasan dan kesejahteraan penduduk secara maksimal. Tingkat pendidikan di Desa Jeruju Besar masih rendah, karena sebagian besar penduduk berpendidikan SMP kebawah (88\%) sedangkan SMA keatas sebesar $12 \%$. Dari tabel tersebut dapat diketahui bahwa sebagian besar tingkat pendidikan penduduk Desa Sungai Bulan adalah tamatan SMP kebawah sebesar $87 \%$ sedangkan SMA keatas sebesar $13 \%$. Artinya tingkat pendidikan di Desa Jeruju Besar masih tergolong rendah. Adapun tingkat pendidikan di Desa Jeruju Besar dan Desa Sungai Bulan dapat dilihat pada tabel 5 berikut ini:

Tabel 5. Jumlah Penduduk Desa Jeruju Besar dan Desa Sungai Bulan Berdasarkan Tingkat Pendidikan

\begin{tabular}{llcccc}
\hline No. & Tingkatan Pendidikan & \multicolumn{2}{c}{ Jeruju Besar } & \multicolumn{2}{c}{ Sungai Bulan } \\
\cline { 3 - 6 } & $\begin{array}{c}\text { Jumlah } \\
\text { Penduduk } \\
\text { (org) }\end{array}$ & $\begin{array}{c}\text { Persentase } \\
\text { (\%) }\end{array}$ & $\begin{array}{c}\text { Jumlah } \\
\text { Penduduk } \\
\text { (org) }\end{array}$ & $\begin{array}{c}\text { Persentase } \\
(\%)\end{array}$ \\
\hline 1 & Belum Sekolah & 412 & 6.8400 & 264 & 10,8900 \\
2 & Tidak pernah sekolah & 251 & 4,2900 & 62 & 2,3500 \\
3 & Tidak Tamat SD & 1125 & 18,7400 & 426 & 17,3600 \\
4 & Tamat SD/Sederajat & 2122 & 35,2400 & 966 & 39.0900 \\
5 & SLTP/Sederajat & 1422 & 23,7720 & 430 & 17,6000 \\
6 & SLTA/Sederajat & 671 & 11,1120 & 261 & 10,7600 \\
7 & D1 & 2 & 0,0003 & 4 & 0,0030 \\
8 & D2 & 8 & 0,0010 & 10 & 0,0070 \\
9 & S1 & 25 & 0,0047 & 48 & 1,9400 \\
\hline & Jumlah & 6.038 & 100 & 2.471 & 100 \\
\hline
\end{tabular}

Sumber: Data Monografi Desa Jeruju Besar dan Desa Sungai Bulan, 2011

\section{3). Mata Pencaharian}

Mata pencaharian penduduk Desa Jeruju Besar dan Desa Sungai Bulan secara umum dipengaruhi oleh kondisi geografis, wilayah, sosial budaya, masyarakat dan beberapa faktor lainnya. Kondisi yang berdekatan dengan daerah pesisir pantai tidak menyusutkan niat masyarakat untuk memilih jalur pertanian 
dan nelayan sebagai penopang kehidupan mereka dan berbagai mata pencaharian lainnya. Sebagian besar penduduk Desa Jeruju Besar dan Desa Sungai Bulan bermata pencaharian sebagai petani. Secara lebih rinci mata pencaharian penduduk Desa Jeruju Besar dapat dilihat pada tabel 6 berikut ini :

Tabel 6. Distribusi Mata Pencaharian Penduduk Desa Jeruju Besar dan Desa Sungai Bulan

\begin{tabular}{llcccc}
\hline No. & Mata Pencaharian & \multicolumn{2}{c}{ Desa Jeruju Besar } & \multicolumn{2}{c}{ Desa Sungai Bulan } \\
\cline { 3 - 6 } & $\begin{array}{c}\text { Jumlah KK } \\
\text { (org) }\end{array}$ & $\begin{array}{c}\text { Persentase } \\
\text { (\%) }\end{array}$ & $\begin{array}{c}\text { Jumlah KK } \\
\text { (org) }\end{array}$ & $\begin{array}{c}\text { Persentase } \\
\text { (\%) }\end{array}$ \\
\hline 1 & Petani & 1452 & 72,170 & 438 & 76,440 \\
2 & Buruh Tani & 233 & 11.260 & 58 & 10,120 \\
3 & Pegawai Negeri & 37 & 1,850 & 15 & 2,620 \\
4 & Pedagang & 88 & 4.370 & 31 & 5,410 \\
5 & Peternak & 103 & 6.120 & 6 & 1,050 \\
6 & Nelayan & 85 & 4.223 & 13 & 2,270 \\
7 & Montir & 15 & 0.007 & 12 & 2,090 \\
\hline & Jumlah & 2013 & 100 & 573 & 100 \\
\hline
\end{tabular}

Sumber: Data Monografi Desa Jeruju Besar dan Sungai Bulan , 2011

\section{B. Karakteristik Responden}

\section{Umur petani}

Umur merupakan salah satu karakteristik yang berbeda antara responden satu dengan responden lainnya yang pada dasarnya sangat mempengaruhi aktivitas konsumsi sehari-hari. Umur responden sangat mempengaruhi jumlah dan jenis makanan yang akan dikonsumsi sehingga akan mempengaruhi ketahanan pangan rumah tangga. Menurut Djojohadikusumo (1994) penggolongan umur dibagi atas usia belum produktif (< 15 tahun), produktif $(15-60$ tahun ) dan tidak produktif $(>60)$.

Berdasarkan hasil penelitian, penyebaran responden menurut umur di Desa Jeruju Besar maupun Desa Sungai Bulan dapat dilihat pada tabel 7 berikut:

Tabel 7. Distribusi Responden Berdasarkan Umur

\begin{tabular}{cccccc}
\hline No. & Kelompok & \multicolumn{2}{c}{ Desa Jeruju Besar } & \multicolumn{2}{c}{ Desa Sungai Bulan } \\
\cline { 3 - 6 } & Umur (thn) & $\begin{array}{c}\text { Jumlah } \\
\text { Responden }\end{array}$ & Persentase & $\begin{array}{c}\text { Jumlah } \\
\text { Responden }\end{array}$ & Persentase \\
\hline 1 & $<15$ & 0 & 0 & 0 & 0 \\
2 & $15-60$ & 63 & 94,0 & 60 & 96,8 \\
3 & $>60$ & 4 & 6,0 & 2 & 3,2 \\
\hline & Jumlah & $\mathbf{6 7}$ & $\mathbf{1 0 0}$ & $\mathbf{6 2}$ & $\mathbf{1 0 0}$ \\
\hline
\end{tabular}

Sumber: Analisis Data Primer 2013

Tabel di atas menunjukkan bahwa sebagian besara umur petani responden tergolong umur produktif di Desa Jeruju Besar sebanyak 63 orang (94,0\%) sedangkan di Desa Sungai Bulan sebanyak 60 orang $(96,8 \%)$ yang tergolong umur produktif. Sementara itu tidak ada responden yang belum produktif atau berada pada umur kurang dari 15 tahun baik di Desa Jeruju Besar maupun Desa Sungai Bulan. 


\section{Pendidikan Responden}

Pendidikan merupakan hal terpenting dalam mengetahui dan memahami suatu persoalan terutama masalah mengenai ilmu gizi. Pendidikan termasuk salah satu faktor yang sangat berpengaruh terhadap pola pikir seseorang.

Pendidikan formal responden adalah jenjang pendidikan yang ditempuh oleh responden, dihitung dari sistem pendidikan sekolah yang telah berhasil ditamatkan oleh responden. Tingkat pendidikan seseorang akan mempengaruhi kebijakan dalam mengambil suatu keputusan untuk mengkonsumsi makanan dalam rumah tangga. Sehingga akan berdampak positif pada ketahanan pangan rumah tangga. Adapun penyebaran responden menurut tingkat pendidikan dapat dilihat pada tabel 8 Berikut ini:

Tabel 8. Distribusi Responden Berdasarkan Tingkat Pendidikan

\begin{tabular}{|c|c|c|c|c|c|}
\hline \multirow[b]{2}{*}{ No } & \multirow{2}{*}{$\begin{array}{c}\text { Tingkat } \\
\text { Pendidikan }\end{array}$} & \multicolumn{2}{|c|}{ Desa Jeruju Besar } & \multicolumn{2}{|c|}{ Desa Sungai Bulan } \\
\hline & & $\begin{array}{c}\text { Jumlah } \\
\text { Responden }\end{array}$ & Persentase & $\begin{array}{c}\text { Jumlah } \\
\text { Responden }\end{array}$ & Persentase \\
\hline 1 & Tidak Sekolah & 4 & 6,0 & 0 & 0 \\
\hline 2 & Tidak Tamat SD & 5 & 7,5 & 2 & 3,02 \\
\hline 3 & SD & 34 & 50,7 & 30 & 48,4 \\
\hline 4 & SLTP & 10 & 14,9 & 17 & 27,4 \\
\hline 5 & SMA/S1 & 14 & 20,9 & 13 & 21,0 \\
\hline & Jumlah & 67 & 100 & 62 & 100 \\
\hline
\end{tabular}

Sumber: Analisis data primer 2013

Berdasarkan tabel 16 di atas menunjukan bahwa kualitas responden bila dilihat dari tingkat pendidikan tergolong rendah, hal in ditunjukan jumlah responden yang mengenyam pendidikan terbanyak merupakan lulusan Sekolah Dasar (SD) baik yang ada di Jeruju Besar Maupun di Desa Sungai Bulan.

Perbedaan tingkat pendidikan berpengaruh terhadap keinovatifan, kecepatan proses adopsi inovasi, dan perilaku seseorang. Tingkat pendidikan juga menentukan karakteristik sikap individu. Semakin tinggi pendidikan responden maka semakin tinggi kemampuan responden untuk mengkonsumsi makanan yang mengandung gizi lengkap yang dibutuhkan tubuh.

\section{Jumlah Anggota Keluarga}

Jumlah tanggungan keluarga memberikan sumbangan yang besar terhadap ketersediaan tenaga kerja, akan tetapi dilain pihak dapat pula menyebabkan semakin tingginya beban ekonomi dalam keluarga terutama dalam jumlah kebutuhan yang akan dikonsumsi keluarga. Jumlah anggota keluarga dalam penelitian ini adalah jumlah anggota yang masih menjadi tanggungan yang terdiri dari istri, anak, orang tua dan saudara terdekat. Penyebaran responden menurut jumlah anggota keluarga dapat dilihat pada tabel 9 berikut ini :

Tabel 9. Distribusi Responden Berdasarkan Jumlah Tanggungan

\begin{tabular}{cccccc}
\hline No. & $\begin{array}{c}\text { Jumlah } \\
\text { Tanggungan } \\
\text { (Orang) }\end{array}$ & \multicolumn{2}{c}{$\begin{array}{c}\text { Desa Jeruju Besar } \\
\text { Jumlah }\end{array}$} & \multicolumn{2}{c}{ Desa Sungai Bulan } \\
\cline { 3 - 6 } & Responden & Persentase & $\begin{array}{c}\text { Jumlah } \\
\text { Responden }\end{array}$ & Persentase \\
\hline 1 & $2-4$ & 45 & 67,2 & 54 & 87,1 \\
2 & $5-7$ & 17 & 25,4 & 8 & 12,9 \\
3 & $>7$ & 5 & 7,4 & 0 & 0 \\
\hline & Jumlah & $\mathbf{6 7}$ & $\mathbf{1 0 0}$ & $\mathbf{6 2}$ & $\mathbf{1 0 0}$ \\
\hline
\end{tabular}

Sumber: Analisis Data Primer 2013 
Berdasarkan tabel di atas dapat diketahui bahwa jumlah anggota keluarga responden sebagian besar berjumlah 2-4 orang di Desa Jeruju Besar maupun Sungai Bulan. Jumlah anggota keluarga berdampak terhadap kecukupan gizi maupun biaya hidup dalam suatu rumah tangga, hal ini disebabkan karena harus membagi dengan jumlah keluarga yang banyak.

\section{Tingkat Pendapatan Responden}

Pendapatan responden merupakan seluruh pemasukan dalam keluarga responden, baik yang berasal dari pendapatan pokok kepala keluarga, pendapatan sampingan kepala keluarga, pendapatan dari istri maupun yang berasala dari pendapatan anggota keluarga. Hasil uji t test menunjukkan perbedaan nyata tingkat pendapatan antar desa pada taraf $\alpha<0,05$ (Lampiran1). Berdasarkan uji t test diketahui bahwa rata-rata pendapatan pada desa Jeruju Besar lebih baik dibanding desa Sungai Bulan.

Tabel 10. Distribusi Responden Berdasarkan Tingkat Pendapatan

\begin{tabular}{cccccc}
\hline No & $\begin{array}{c}\text { Tingkat } \\
\text { Pendapatan }\end{array}$ & $\begin{array}{c}\text { Desa Jeruju Besar } \\
\text { Jumlah } \\
\text { Responden }\end{array}$ & Persentase & $\begin{array}{c}\text { Desa Sungai Bulan } \\
\text { Jesponden }\end{array}$ & Persentase \\
\hline 1 & $<1.500 .000$ & 7 & 10,5 & 23 & 37,1 \\
2 & $1.500 .000-3.000 .000$ & 51 & 76,1 & 33 & 53,2 \\
3 & $>3.000 .000$ & 9 & 13,4 & 6 & 9,7 \\
\hline \multicolumn{2}{c}{ Jumlah } & $\mathbf{6 7}$ & $\mathbf{1 0 0}$ & $\mathbf{6 2}$ & $\mathbf{1 0 0}$ \\
\hline
\end{tabular}

Sumber: Analisis Data Primer 2013

Berdasarkan tabel 10 di atas dapat diketahui bahwa sebagian besar responden memiliki tingkat pendapatan yang berkisar antara Rp.1.500.000,00 - Rp.3.000.000,00 Hal ini didukung oleh pekerjaan responden yang memiliki usaha rumah tangga, sehingga pendapatan responden tinggi. Daerah penelitian ini adalah termasuk Desa dengan program Demapan (Desa Mandiri Pangan merupakan daerah yang termasuk rawan pangan terutama kesulitan akses pangan. Program ini sudah berjalan dengan baik, indikator yang dapat dilihat adalah tingkat pendapatan masyarakat sudah cukup tinggi berkisar antara Rp.1.500.000,00 - Rp.3.000.000,00

\section{Pengetahuan Gizi}

Pengetahuan gizi dinilai dari pemahaman contoh tentang keanekaragaman konsumsi pangan kaitannya dengan kesehatan. Hasil Uji t test (Lampiran 2) tidak menunjukkan perbedaan nyata pengetahuan gizi keluarga contoh antar desa pada taraf $\alpha<0,05$. Rata-rata nilai pengetahuan gizi pada desa Jeruju Besar lebih baik dibanding desa Sungai Bulan berturut-turut adalah 5,23 untuk desa Jeruju Besar dan 5,21 untuk desa Sungai Bulan (Tabel 11).

Tabel 11. Rata-rata Nilai Pengetahuan Gizi

\begin{tabular}{lrc}
\hline \multirow{2}{*}{ Desa } & \multicolumn{2}{c}{ Nilai Pengetahuan Gizi } \\
\cline { 2 - 3 } & Rata-rata & Simpangan baku \\
\hline Jeruju Besar & 6,3582 & 3,24131 \\
Sungai Bulan & 5,3387 & 2,66085 \\
\hline & 5,84845 & 2,95108 \\
\hline
\end{tabular}

Sumber: Analisis Data Primer 2013

Fakta di atas menunjukkan keluarga contoh di Desa Jeruju Besar lebih mudah dan cepat mendapatkan informasi dibanding Desa Sungai Bulan meskipun tidak berbeda secara nyata. Hal ini dikarenakan pada Desa Jeruju Besar sarana dan 
prasarana yang mendukung akses informasi dan transportasi lebih tersedia dibandingkan Desa Sungai Bulan.

Pengetahuan gizi yang baik merupakan salah satu faktor penentu dalam pemilihan pangan yang akan dikonsumsi. Jika pengetahuan gizi cukup maka seseorang dapat melakukan pilihan yang sesuai dengan kaidah kesehatan sesuai dengan akses yang dimiliki. Namun demikian pengetahuan gizi yang baik akan kurang bermanfaat bila tidak diikuti dengan sikap dan praktek dalam kehidupan sehari-hari.

\section{Tingkat Keanekaragaman Konsumsi Pangan}

Untuk mengukur keanekaragaman konsumsi pangan dalam penelitian ini digunakan dengan skor PPH (Pola Pangan Harapan). Pola Pangan Harapan adalah komposisi/susunan pangan atau kelompok pangan yang didasarkan pada kontribusi energinya baik mutlak maupun relatif yang memenuhi kebutuhan gizi secara kuantitas, kualitas, maupun keragamannya dengan mempertimbangkan aspek sosial, ekonomi, budaya, agama dan cita rasa. Skor PPH yaitu nilai yang menunjukkan kualitas konsumsi pangan yang beragam, bergizi seimbang dan aman, yang dihitung berdasarkan metode PPH.

Hasil penelitian menunjukkan rata-rata skor PPH baru mencapai 71,56 dari skor PPH ideal yaitu 100 (Tabel 20). Begitu pula bila dilihat per kelompok pangan, semua skor PPH untuk setiap kelompok pangan di wilayah penelitian masih dibawah skor idial. Skor PPH idial untuk Padi-padian 25,0; umbi-umbian 2,5; Pangan hewani, 24,0; Minyak dan Lemak 5,0; Buah/Biji Berminyak 1,0; Kacang-kacangan 10,0; Gula 0,5; Sayur dan buah 30,0 dan lainnya 0,0.

Tabel 12. Rata-rata Skor PPH di Wilayah Penelitian Dibandingkan Skor PPH Ideal

\begin{tabular}{|c|c|c|c|c|c|}
\hline \multirow{2}{*}{ No } & \multirow{2}{*}{ Kelompok Pangan } & \multicolumn{2}{|c|}{ Skor PPH } & \multirow{2}{*}{ Skor PPH } & \multirow{2}{*}{$\begin{array}{c}\text { Skor PPH } \\
\text { Ideal }\end{array}$} \\
\hline & & Jeruiu Besar & Sungai Bulan & & \\
\hline 1. & Padi-padian & 23.45 & 20.49 & 21.97 & 25.00 \\
\hline 2. & Umbi-umbian & 0.42 & 1.42 & 0.92 & 2.50 \\
\hline 3. & Pangan Hewani & 11.78 & 9.10 & 10.44 & 24.00 \\
\hline 4. & Minyak dan Lemak & 3.50 & 4.90 & 4.20 & 5.00 \\
\hline 5. & Buah/biji berminyak & 0.40 & 0.20 & 0.30 & 1.00 \\
\hline 6. & Kacang-kacangan & 5.98 & 6.06 & 6.02 & 10.00 \\
\hline 7. & Gula & 1.08 & 1.16 & 1.12 & 2.00 \\
\hline 8. & Sayuran dan buah & 21.89 & 25.21 & 23.55 & 30.00 \\
\hline \multirow[t]{2}{*}{9.} & Lain-lain & 0.00 & 0.00 & 0.00 & 0.00 \\
\hline & Jumlah & 68.50 & 68.54 & 68.52 & 100.00 \\
\hline
\end{tabular}

Sumber: Analisis Data Primer 2013

Skor PPH hasil penelitian 68,52, dimana lebih rendah bila dibandingkan dengan Skor PPH Kalimantan Barat untuk tahun 2010 sebesar 71,79. Hal yang sama juga terjadi untuk skor PPH setiap per kelompok pangan. Lebih rendahnya skor PPH di wilayah penelitian dibanding skor PPH Kalimantan Barat Tahun 2010 diduga karena pada saat penelitian terjadi kenaikan harga beberapa komoditas.

Hasil Uji t test menunjukkan terdapat perbedaan tidak nyata skor PPH antar desa pada taraf $\alpha 5 \%$ (Lampiran 3). Rata-rata nilai PPH pada desa Jeruju Besar adalah sebesar 68,5030 dan desa Sungai Bulan 68,5355 (Tabel 13). Secara statistik skor PPH antar desa tidak berpengaruh sehingga tidak terdapat perbedaan antara skor PPH desa Jeruju Besar dibandingkan desa Sungai Bulan. 
Tabel 13. Rata-rata Skor PPH

\begin{tabular}{lcc}
\hline \multirow{2}{*}{ Desa } & \multicolumn{2}{c}{ Skor PPH } \\
\cline { 2 - 3 } & Rata-rata & Simpangan baku \\
\hline Jeruju Besar & 68.5030 & 8.4645 \\
Sungai Bulan & 68.5355 & 10.5078 \\
\hline & 68.519 & 9.4862
\end{tabular}

Sumber: Analisis Data Primer 2013

\section{E. Hubungan Antara Aspek Sosial Ekonomi Terhadap Keanekaragaman Konsumsi pangan (Skor PPH)}

Untuk melihat berbagai faktor yang diduga berpengaruh terhadap tingkat keanekaragaman konsumsi pangan (sebagai variabel $Y$ ) dilakukan dengan uji regresi berganda. Beberapa variabel yang diduga berpengaruh (sebagai variabel $\mathrm{X}$ ) dan dimasukkan dalam uji regresi berganda meliputi pendapatan per kapita, pendidikan ayah/ibu, jumlah anggota keluarga. Analisis regresi yang digunakan adalah metode stepwise yaitu analisis regresi secara bertahap dengan tujuan utama untuk mencari variabel yang dominan. Hasil uji regresi berganda dengan metode stepwise sebagaimana lampiran 4 terdapat 3 variabel yang dimasukkan yaitu pendapatan, pendidikan kepala rumah tangga dan jumlah anggota keluarga.. Hasil tersebut menunjukkan bahwa faktor yang berpengaruh terhadap keanekaragaman konsumsi pangan (skor PPH) adalah pendapatan perkapita, pendidikan kepala rumah tangga dan jumlah anggota keluarga dengan persamaan sebagai berikut:

\section{a Jeruju Besar}

$Y=64,743+2,704 X_{1}+0,917 X_{2}-2,192 X_{3}+e$

$\mathrm{Y}=$ skor $\mathrm{PPH}$

$\mathrm{X}_{1}=$ pendapatan per kapita

$\mathrm{X}_{2}=$ pendidikan kepala rumah tangga

$\mathrm{X}_{3}=$ Jumlah anggota keluarga $\quad \mathrm{R}=0,728$

1) Variabel $\left(X_{1}\right)$ terhadap $(Y)$

Dari persamaan regresi tampak bahwa apabila nilai koefisien pendapatan keluarga untuk variable $X_{1}$ adalah sebesar 2,704 dan bertanda positif $(+)$ hal ini mengandung arti bahwa setiap kenaikan variabel $X_{1}$ satu satuan maka variable (Y) akan naik sebesar 2,704 dengan asumsi bahwa variable bebas yang lain dari model regresi adalah tetap. Hal ini berarti bahwa semakin bertambah variabel $\mathrm{X}_{1}$ maka akan terjadi peningkatan $\mathrm{Y}$. Berdasarkan hasil persamaan regresi linier berganda tampak bahwa nilai t-hitung 4,784 > 1,997 t-tabel maka ha di terima dan ho ditolak ini artinya adalah bahwa variabel $X_{1}$ berpengaruh signifikan terhadap $Y$ ini menunjukan bahwa apabila variabel $X_{1}$ bertambah semakin tinggi (besar) maka variabel $Y$ juga akan semakin meningkat.

2) Variabel $\left(X_{2}\right)$ terhadap $(Y)$

Dari persamaan regresi tampak bahwa nilai koefisien pendidikan kepala rumah tangga untuk variabel $X_{2}$ sebesar 0,917 dan bertanda negatif $(+)$ hal ini mengandung artinya bahwa setiap kenaikan variabel $X_{2}$ satu satuan maka variable $(Y)$ akan naik sebesar 0,917 dengan asumsi bahwa variabel bebas yang lain dari model regresi adalah tetap. Hal ini mengandung arti bahwa semakin bertambah variabel $\mathrm{X}_{2}$ maka akan terjadi peningkatan variabel $\mathrm{Y}$. Berdasarkan hasil persamaan regresi linier berganda tampak bahwa nilai t- 
hitung $2.823>1,997$ t-tabel dan bertanda possitif $(+)$ maka ha di terima dan ho ditolak ini artinya adalah bahwa variabel $X_{2}$ berpengaruh signifikan terhadap $Y$ sehingga setiap terjadi penambahan variabel $X_{2}$ menyebabkan peningkatan variabel Y.

3) Variabel $\left(X_{3}\right)$ terhadap $(Y)$

Dari persamaan regresi tampak bahwa nilai koefisien jumlah anggota keluarga rumah tangga untuk variabel $X_{3}$ adalah sebesar -2,192 dan bertanda negatif (-) hal ini mengandung arti bahwa setiap kenaikan variabel $X_{3}$ satu satuan maka variabel $(Y)$ akan turun sebesar 2,192 dengan asumsi bahwa variabel bebas yang lain dari model regresi adalah tetap. Berdasarkan hasil persamaan regresi linier berganda tampak bahwa t-hitung $-2,867<1,997 \mathrm{t}$ tabel dengan mengabaikan nilai (-) maka ha di terima dan ho ditolak ini artinya adalah bahwa variabel $X_{3}$ berpengaruh signifikan terhadap $Y$ sehingga setiap terjadi penambahan variabel $\mathrm{X}_{3}$ menyebabkan penurunan variabel $\mathrm{Y}$.

\section{b. Sungai Bulan}

$Y=64,404+6,982 X_{1}+0,348 X_{2}-3.310 X_{3}+e$

$\mathrm{Y}=$ skor $\mathrm{PPH}$

$\mathrm{X}_{1}=$ pendapatan per kapita

$\mathrm{X}_{2}=$ pendidikan kepala rumah tangga

$\mathrm{X}_{3}=$ Jumlah anggota keluarga $\quad \mathrm{R}=0,743$

1) Variabel $\left(X_{1}\right)$ terhadap $(Y)$

Dari persamaan regresi tampak bahwa apabila nilai koefisien pendapatan keluarga untuk variable $X_{1}$ adalah sebesar 6,982 dan bertanda positif $(+)$ hal ini mengandung arti bahwa setiap kenaikan variable $\left(X_{1}\right)$ satu satuan maka variable ( $\mathrm{Y}$ ) akan naik sebesar 6,982 dengan asumsi bahwa variable bebas yang lain dari model regresi adalah tetap. Hal ini berarti bahwa semakin variable $\mathrm{X}_{1}$ bertambah maka $(\mathrm{Y})$ akan meningkat. Berdasarkan hasil persamaan regresi linier berganda tampak bahwa nilai t-hitung 4,582 > 2,000 ttabel dan bertanda $(+)$ maka ha di terima dan ho ditolak ini artinya adalah bahwa variable $X_{1}$ berpengaruh signifikan terhadap $Y$ ini menunjukan bahwa apabila variable $X_{1}$ bertambah semakin tinggi (Besar) maka $Y$ akan semakin meningkat.

2) Variabel $\left(\mathrm{X}_{2}\right)$ terhadap $(\mathrm{Y})$

Dari persamaan regresi tampak bahwa nilai koefisien variabel $\mathrm{X}_{2}$ sebesar 0,348 dan bertanda positif $(+)$ hal ini mengandung artinya bahwa setiap kenaikan variable $X_{2}$ satu satuan maka variable $(Y)$ akan naik sebesar 0,348 dengan asumsi bahwa variabel bebas yang lain dari model regresi adalah tetap. Artinya bahwa semakin bertambah variable $X_{2}$ maka $Y$ akan meningkat. Berdasarkan hasil persamaan regresi linier berganda tampak bahwa nilai t-hitung $0.769<2,000$ t-tabel dan bertanda (+) maka ha ditolak dan ho di terima ini artinya adalah bahwa variable $\mathrm{X}_{2}$ tidak berpengaruh signifikan terhadap $\mathrm{Y}$.

3) Variabel $\left(X_{3}\right)$ terhadap $(Y)$

Dari persamaan regresi tampak bahwa nilai koefisien variabel $\mathrm{X} 3$ adalah sebesar -3.310 dan bertanda (-) hal ini mengandung artinya bahwa setiap kenaikan variable $\mathrm{X} 3$ satu satuan maka variabel $(\mathrm{Y})$ akan turun sebesar 3,310 
dengan asumsi bahwa variabel bebas yang lain dari model regresi adalah tetap. Berdasarkan hasil persamaan regresi linier berganda tampak bahwa thitung $-2.200>2,000$ t-tabel dengan mengabaikan nilai (-) maka ha diterima dan ho ditolak ini artinya adalah variabel $\mathrm{X}_{3}$ berpengaruh signifikan terhadap $\mathrm{Y}$. Ini menunjukan bahwa apabila variabel $X_{3}$ semakin bertambah maka $Y$ akan semakin kecil.

\section{c. Pembahasan Aspek Sosial Ekonomi Terhadap Keanekaragaman Konsumsi pangan (Skor PPH)}

\section{1) Pendapatan $\left(X_{1}\right)$ terhadap Skor PPH $(Y)$}

Hasil analisis di desa jeruju besar dan desa sungai bulan menunjukkan pendapatan berpengaruh nyata terhadap Skor PPH. Semakin tinggi pendapatan maka Skor PPH atau keanekaragaman konsumsi pangan semakin baik Artinya keberhasilan dalam percepatan keanekaragaman konsumsi pangan akan sangat ditentukan oleh tingkat keberhasilan dalam hal perbaikan pendapatan keluarga. Walaupun masih terdapat faktor lain yang juga berpengaruh terhadap keanekaragaman konsumsi pangan.

Pendapat tersebut sesuai dengan hasil penelitian Ni Made Suyastiri Y.P (2008) menyatakan faktor-faktor yang mempengaruhi pola diversifikasi konsumsi pangan dalam mewujudkan ketahanan pangan pada rumahtangga pedesaan adalah pendapatan rumahtangga, harga pangan dan jumlah anggota keluarga.

\section{2) Pendidikan $\left(\mathbf{X}_{2}\right)$ terhadap Skor PPH}

Hasil analisis di desa jeruju besar menunjukkan pendidikan berpengaruh nyata terhadap skor PPH dan berpengaruh tidak nyata terhadap skor PPH pada desa sungai bulan. Semakin tinggi pendidikan maka skor PPH atau keanekaragaman konsumsi pangan semakin baik

Pada desa sungai bulan faktor pendidikan berpengaruh tidak nyata terhadap skor $\mathrm{PPH}$ atau keanekaragaman konsumsi pangan diduga karena akses pangan (jalan) untuk menuju desa sungai bulan cukup sulit. Sulitnya akses pangan ini menyebabkan informasi pengetahuan gizi menjadi rendah.

Peningkatan pendidikan akan meningkatkan keanekaragaman konsumsi pangan. Penelitian ini sesuai hasil penelitian Mardiana dan Bambang (2009) dimana pendapatan, pendidikan dan kepemilikian aset produktif berpengaruh terhadap kerawanan pangan Desa Wiru Kecamatan Bringin Kabupaten Semarang. Faktor pendidikan berhubungan dengan pengetahuan akan gizi, dimana semakin tinggi pendidikan masyarakat pengetahuan akan gizi semakin lebih baik.

\section{3) Jumlah Anggota Keluarga $\left(\mathrm{X}_{3}\right)$ terhadap Skor PPH ( $Y$ )}

Hasil analisis di desa jeruju besar dan desa sungai bulan menunjukkan jumlah anggota keluarga berpengaruh nyata dan berbanding terbalik terhadap Skor PPH. Semakin besar jumlah anggota keluarga maka Skor PPH atau keanekaragaman konsumsi pangan semakin rendah. Jumlah anggota keluarga berhubungan dengan proporsi alokasi pengeluaran untuk konsumsi pangan. Penelitian Munparidi (2010) menyatakan bahwa proporsi alokasi pengeluaran untuk konsumsi pangan berbanding terbalik dengan besarnya pendapatan total keluarga. 


\section{PENUTUP}

\section{A. Kesimpulan}

1. Berdasarkan wilayah skor PPH di Wilayah penelitian sebesar 68,52 masih rendah dibandingkan skor PPH Kalimantan Barat sebesar 71,79 dan skor PPH ideal sebesar 100. Walaupun demikian skor PPH Desa Jeruju Besar tidak berbeda nyata dibandingkan skor PPH Desa Sungai Bulan.

2. Faktor yang mempengaruhi Skor PPH pada Desa Jeruju Besar adalah pendapatan, pendidikan dan jumlah tanggungan keluarga. Sedangkan pada Desa Sungai Bulan adalah pendapatan dan jumlah tanggungan keluarga. Sehingga faktor pendapatan, pendidikan dan jumlah tanggungan merupakan kunci yang sangat menentukan tingkat keragaman pangan yang dikonsumsi masyarakat.

\section{B. SARAN}

1. Perlu penelitian lanjutan dalam menganalisis komponen sub sistem agribisnis yang berkaitan dengan ketersediaan dan keragaman pangan yang dikonsumsi.

2. Perlu penanganan secara sinergis antara satu faktor dengan faktor lainnya yang dikaitkan dengan tingkat keanekaragaman konsumsi pangan. Faktor kunci yang berpengaruh adalah pendapatan, pendidikan dan jumlah taggungan keluarga disertai ketersediaan pangan yang cukup. Pemerintah segera melakukan percepatan keanekaragaman konsumsi pangan dengan upaya perbaikan ekonomi untuk meningkatkan pendapatan dan pendidikan, yakni dengan menggalakkan aktivitas agribisnis (pertanian, peternakan dan perikanan) untuk meningkatkan kesempatan kerja dan memberikan peluang tambahan penghasilan namun harus dibarengi dengan memperluas gerakan keluarga berencana.

3. Pemerintah perlu memberikan insentif dan stimulant guna menumbuhkan industry pangan lokal di tingkat rumah tangga untuk meningkatkan ketersediaan pangan di wilayah tersebut.

4. Pemerintah perlu mendorong percepatan diversifikasi pangan melalui Gerakan Percepatan Penganekaragaman Konsumsi Pangan (P2KP) Berbasis Sumberdaya Lokal yang melibatkan berbagai kelompok masyarakat.

\section{DAFTAR PUSTAKA}

Arikunto, S. 2002. Prosedur Penelitian. Penerbit Rineka Cipta. Jakarta.

Ariawan, I. 1998. Besar dan Ukuran Sampel pada Penelitian Kesehatan. Program

Badan Ketahanan Pangan dan Penyuluhan Provinsi Kalimantan Barat, 2011. Laporan Tahunan. Pontianak.

Badan Pemberdayaa Masyarakat, Pemberdayaan Perempuan, Pemerintahan Desa, dan KB, 2009. Laporan Tahunan. Sungai Raya.

Bagia Ketahanan Pangan Sekretariat Daerah Kabupaten Kubu Raya, 2011. Laporan Tahunan. Sungai Raya.

Berg, A. 1986. Peranan Gizi Dalam Pembangunan. CV Rajawali. Jakarta.

Bunasor, 1989. Aspek Teknologi, Sosial, dan Ekonomi dalam Diversifikasi Pangan.

Tinjauan dari Sisi Produksi dan Konsumsi. Seminar Studi Kebijakan Pangan dan Gizi: Pengalaman dan Harapan, Darmaga, Bogor.

Damardjati, D. S., 2007. Kebijakan dan Program Nasional Pengembangan Agribisnis 
Palawija. Hal 51-63. Dalam: Rusastra, I.W., T.A.Napitupulu, M.O. A. Manikmas, F.Kasim (Eds), Pengembangan Agribisnis Berbasis Palawija di Indonesia: Perannya dalam Peningkatan Ketahanan Pangan dan Pengentasan Kemiskinan. CAPSA Monograph No. 49, United Nations E S C A P; Puslitbang Tanaman Pangan.Prosiding Seminar Nasional Bogor, 13 Juli 2006.

Depkes R.I., 2005. Rencana Aksi Nasional Pencegahan dan Penanggulangan Gizi Buruk 2005-2009. Jakarta.

Dewan Ketahanan Pangan (DKP). 2006. Kebijakan Umum Ketahanan Pangan. Dewan Ketahanan Umum. Jakarta.

Dinas Pertanian dan Peternakan Kabupaten Kubu Raya, 2005. Laporan Tahunan. Sungai Raya.

Fathiyah, U.Sumarwan dan I.Tanziha. 2005. Analisis Pengetahuan Gizi dan Produk Minuman Sari Buah Kemasan Dihubungkan Dengan Merek yang Dikonsumsi Sebagai Sumber Protein Hewani. Media Gizi dan Keluarga, Vol.29 No.2: 7587

FAO-RAPA. 1989. Toward Nutritional Adequacy in Asia-Pacific Region. FAO Regional Office for Asia and The Pacific. Bangladesh

Forum Kerja Penganekaragaman. 2003. Penganekaragaman Pangan. Hal. i-iii. Dalam Hadiriyadi, P., B.Krisnamurti, dan F.G.Winarno (Eds.), Hasil-Hasil Simposium Penganekaragaman Pangan. Prakarsa Swasta dan pemerintah Daerah. Jakarta http://www.fp.brawijaya 2007. Pengembangan Agribisnis. Diakses tanggal 23 april 2008

Kodyat, B. 1997. Penuntasan Masalah Gizi Utama. Semiloka Pra Widyakarya. Martianto, D.dan M.Ariani. 2004. Analisis Perubahan Konsumsi dan Pola

Konsumsi Pangan Masyarakat dalam Dekade Terakhir. Prosiding Widyakarya Nasional Pangan dan Gizi VII. LIPI Jakarta. 2011.

Moenek A. 2007. Gerakan Percepatan Diversifikasi Konsumsi Pangan 2007-2015.

Mubyarto dan A. Santosa 2003. Pembangunan Pertanian Berkelanjutan (Kritik Terhadap Paradigma Agribisnis). Jurnal Ekonomi Rakyat, Th 3, No.3. www.ekonomirakyat.org. Diakses Tanggal 11 Maret 2008

Munparidi. 2010. Pengaruh Pendapatan Dan Ukuran Keluarga Terhadap Pola Konsumsi Studi Kasus : Desa Ulak Kerbau Lama Kecamatan Tanjung Raja Kabupaten Ogan Ilir. ILMIAH Volume II No.3, 2010. Riau.

Nainggolan, 2008. Perencanaan Pangan Menuju Ketahanan Pangan dan Gizi. Pusat Kajian Pangan Universitas Sumatera Utara. Medan.

Nurkukuh 2000. Model KIE Pencegahan Dini Penyakit Jantung Koroner di Masyarakat. Fakultas Kesehatan Masyarakat, Universitas Diponegoro. Obert, C.J. 1978. Community Nutrition. John Wiley \& Sons. New York.

Pakpahan, A., dan S.H. Suhartini. 1990. Perkembangan Keanekaragaman

Konsumsi Pangan Rumah Tangga Kota di Indonesia. Forum Statistik No.3 tahun IX . Jakarta

Prihananto, V. 2001. Strategi Membangun Ketahanan Pangan dan Gizi Melalui Kemandirian Lokal. Makalah disampaikan pada acara seminar Hari Pangan Sedunia Th. 2001 di Kabupaten Purbalingga, tgl 17 Oktober 2001. 
Pusat Konsumsi dan Keamanan pangan. 2007. Pedoman Umum Gerakan Percepatan Diversifikasi Konsumsi Pangan 2007 - 2015. Badan Ketahanan Pangan. Jakarta

.2011. Prosiding Seminar Nasional Penguatan Sosial Ekonomi Pertanian Menuju Kesejahteraan Masyarakat. Universitas Gajahmada. Yogyakarta.

Sidik, M dan S. Purnomo. 1989. Upaya Penganekaragaman Penyediaan Pangan dalam Rangka Mengurangi Ketergantungan pada Konsumsi Beras. Makalah pada seminar Upaya perbaikan konsumsi pangan dan gizi masyarakat menyongsong era lepas landas, Bogor 2 desenber. PAU Pangan dan gizi IPB Bogor.

Soekirman. 1991. Dampak Perkembangan Pembangunan Terhadap Keadaan Gizi Masyarakat. Pidato Penerimaan Jabatan Guru Besar Luar Biasa IImu Gizi. Bogor.

Soekirman. 2000. IImu Gizi dan Aplikasinya. Direktorat Jenderal Pendidikan Tinggi, Departemen Pendidikan Nasional. Jakarta.

Sugiyono. 2011. Statistika untuk Penelitian. Alfabeta. Bandung.

Suhardjo, 1989 . Sosio Budaya Gizi. Pusat Antar Universitas Pangan dan Gizi, Institut Pertanian Bogor.

Sulaeman A., 1995. Diversifikasi Pangan. Pelatihan Pengembangan Kurikulum Bidang Pangan dan Gizi, Jurusan Gizi Masyarakat dan Sumber daya Keluarga IPB bekerjasama dengan Bagian Proyek Pengembangan Kesehatan dan Gizi Masyarakat, DITBINLITABMAS, DIKTI.

Suhardjo. 1998. Konsep dan Kebijakan Diversifikasi Konsumsi Pangan dalam Rangka Ketahanan Pangan. Prosiding Widyakarya Nasional Pangan dan Gizi VI. LIPI Jakarta.

Suryana (2007 Strategi Kebijakan Penelitian dan Pengembangan Palawija. Hal 2350. Dalam: Rusastra, I.W., T.A.Napitupulu, M.O. A. Manikmas, F.Kasim (Eds), Pengembangan Agribisnis Berbasis Palawija di Indonesia: Perannya dalam Peningkatan Ketahanan Pangan dan Pengentasan

Kemiskinan. CAPSA Monograph No. 49, United Nations E S C A P; Puslitbang Tanaman Pangan.Prosiding Seminar Nasional Bogor, 13 Juli 2006

Suryanto,B .2004. Peran Usahatani Ternak Ruminansia dalam Pembangunan Agribisnis Berwawasan Lingkungan, Pidato Pengukuhan Guru

Besar dalam IImu Manajemen Usahatani ,Universitas Diponegoro, Penerbit BP Undip ISBN 979.704.266.9

UNICEF. 1997. Laporan Situasi Anak-Anak Di Dunia 1997. Penebar Swadaya, Kantor Perwakilan UNICEF untuk Indonesia.

UNICEF. 1998. The State of The Word's Children. Oxford Univ. Press. 